\title{
Notes on Reproduction of the Cuban Lesser Racer, Caraiba andreae (Squamata: Dipsadidae)
}

Tomás M. Rodríguez-Cabrera ${ }^{1}$, Alexander Arango Leyva ${ }^{2}$, Ernesto Morell Savall ${ }^{3}$, Javier Torres ${ }^{4}$, and Ruben Marrero 5

${ }^{1}$ Jardín Botánico de Cienfuegos, Cienfuegos, CP 59290, Cuba (tomasmichel.rodriguez@gmail.com)

2Parque Zoológico Nacional de Cuba, La Habana, CP 10800, Cuba (alexander@cubazoo.cu)

${ }^{3}$ Área Protegida “Sabanas de Santa Clara,” Empresa Nacional para la Protección de la Flora y la Fauna, Villa Clara, CP 50100, Cuba (ernestomorell68@nauta.cu) ${ }^{4}$ Departamento de Biología Animal y Humana, Facultad de Biología, Universidad de La Habana, La Habana, CP 10400, Cuba (javiertorres@fbio.uh.cu) ${ }^{5}$ División de Zoología de Vertebrados, Instituto de Ecología y Sistemática, La Habana, CP 10800, Cuba (rubens@ecologia.cu)

Abstract.-The reproductive biology of the Cuban Lesser Racer (Caraiba andreae) is very poorly known, despite the species being among the most common and widely distributed snakes in Cuba. Herein we provide data obtained mostly in captivity on eggs and hatchlings, incubation time, hatching behavior, and courtship behavior.

$\mathrm{T}$ he West Indian snake tribe Alsophiini (Dipsadidae) comprises 10 genera and 49 species (Hedges et al. 2009; Henderson and Powell 2009). However, reliable data on reproductive biology are available for only 18 species (37\%), and most of those are isolated observations of courtship, oviposition, and/or hatchlings (see Henderson and Powell 2009 for a review). Ten species of alsophines in three genera (Arrhyton, Caraiba, and Cubophis) occur in the Cuban Archipelago, and the only species for which extensive reproductive data are available is the Cuban Racer, Cubophis cantherigerus (Garrido 1973; Petzold 1978; Novo and Arazoza 1986; Fong and Garcés 2002; Domínguez and Moreno 2003, 2006; Arango 2008). The reproductive biology of the remaining species is virtually unknown.

The endemic Cuban Lesser Racer, Caraiba andreae (Reinhardt and Lütken 1862) (Fig. 1) represents a monotypic genus (Hedges et al. 2009; Zaher et al. 2009). This polytypic species comprises six subspecies distributed across the main island, Isla de la Juventud and some adjacent keys at elevations from sea level to 1,293 m (Schwartz and Henderson 1991; Henderson and Powell 2009; Rodríguez et al. 2010; Estrada 2012). Thomas and Garrido (1967) and Estrada (1994) reported mating in nature, but offered few details. Grant (1957) mentioned that "most of the females" of $C$. a. orientalis collected by him on 5-26 April 1956 at Banes, Holguín Province "contained four to six yolks $10 \mathrm{~mm}$. long by half that width" and briefly described hatchlings. Schwartz and Henderson (1991) and Fong (2004) described egg clutches. Herein we provide data obtained mostly in captivity for 44 eggs and 31 hatchlings from six clutches. We also provide information regarding incubation time, hatching behavior, hatchling growth and coloration, and courtship behavior.

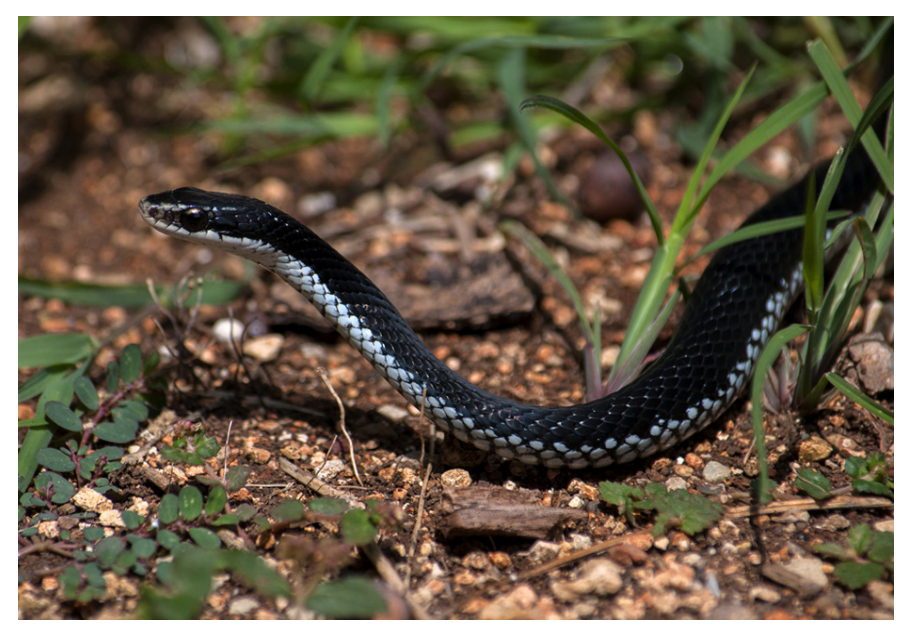

Fig. 1. Typical adult Cuban Lesser Racer (Caraiba a. andreae) from Canasí, northern coast of Mayabeque Province, Cuba. Photograph by Raimundo López-Silvero.

\section{Materials and Methods}

We collected snakes in the wild between 2007 and 2014 and kept them in glass terraria $(85 \times 30 \times 35 \mathrm{~cm})$. We fed adults once a week, providing anoles (Anolis homolechis, A. porcatus, A. sagrei) or frogs (Eleutherodactylus spp. or juvenile Osteopilus septentrionalis). We monitored the growth of five hatchlings (Table 2: No. 3B) for four months, during which they were fed juvenile Eleutherodactylus frogs (0.2-0.7 g) every 4-7 days. Water was provided ad libitum for all individuals.

Eggs were incubated in Petri dishes (diameter $16 \mathrm{~cm}$, depth $3 \mathrm{~cm}$ ) (Table 1: Nos. 3A, 3B, and 4), placed in a plastic container $(16 \times 12 \times 7 \mathrm{~cm})$ (Table 1: No. 5), or left where they were laid in the terraria (Table 1: Nos. 1 and 2). We used five types of substrate for incubation: (1) humus-magnesian 
Table 1. Measurements of female Cuban Lesser Racers (Caraiba andreae) and eggs from the literature and this paper. SVL $=$ snout-vent length of females $(\mathrm{mm}), \mathrm{N}=$ number of eggs per clutch, length and width $(\mathrm{mm})$ given as mean and range (in parentheses), $\mathrm{TCM}=$ total clutch mass $(\mathrm{g}), x / \mathrm{E}=$ mean mass $(\mathrm{g})$ per egg. Totals listed as mean \pm one standard deviation. Measurements of clutch No. 5 were taken just before hatching.

\begin{tabular}{|c|c|c|c|c|c|c|c|}
\hline \multicolumn{3}{|c|}{ Female } & \multicolumn{4}{|c|}{ Eggs } & \multirow[t]{2}{*}{ Source } \\
\hline No. & SVL & $\mathrm{N}$ & Length & Width & TCM & $/ \mathrm{E}$ & \\
\hline- & 294 & 3 & 19.3 & 6.0 & - & - & Schwartz and Henderson (1991) \\
\hline - & 310 & 3 & $30.8(30.1-31.2)$ & $8.6(8.1-9.2)$ & - & - & Fong (2004) \\
\hline 1 & 420 & 7 & $22.1(20.2-24.4)$ & $9.3(8.9-9.5)$ & 7.6 & 1.1 & This paper \\
\hline 2 & 460 & 9 & $22.4(19.7-25.3)$ & $9.1(8.7-9.5)$ & 9.4 & 1.0 & This paper \\
\hline $3 \mathrm{~A}$ & 410 & 6 & $22.4(20.5-24.2)$ & $9.0(7.3-9.5)$ & 7.3 & 1.2 & This paper \\
\hline 3B & Ibid. & 5 & $20.5(15.2-25.7)$ & $8.7(8.2-9.3)$ & 4.9 & 1.0 & This paper \\
\hline 4 & 450 & 6 & $22.2(20.5-24.2)$ & $9.3(9.1-9.5)$ & 6.8 & 1.1 & This paper \\
\hline 5 & - & 5 & $20.8(19.9-22.0)$ & $12.7(12.5-12.9)$ & - & - & This paper \\
\hline Total & & 44 & $22.4 \pm 3.0$ & $9.4 \pm 1.4$ & & & \\
\hline
\end{tabular}

sialitic and ferralitic soil (serpentine soil) (Table 1: Nos. 1 and 2), (2) an equal mixture of ferralitic soil and vegetable matter (Table 1: No. 3A), (3) neutral sand (Table 1: No. 3B), (4) peat (Table 1: No. 4), and (5) soil (Table 1: No. 5). We maintained moisture by periodically (every two or three days) spraying water with an atomizer to keep relative humidity at $85-90 \%$. Incubation temperatures varied from $25-31^{\circ} \mathrm{C}$.

We measured eggs to the nearest $0.05 \mathrm{~mm}$ with a Stainless Steel Vernier Caliper and weighed egg clutches to the nearest $0.01 \mathrm{~g}$ with a Portable Electronic Balance. Because eggs of the same clutch were strongly adherent and separating them entailed a high risk of rupture, a mean mass per egg was calculated by dividing the total clutch mass by the number of eggs in the clutch. Both adults and hatchlings were measured for snout-vent length (SVL) and tail length (TL) to the nearest millimeter with a flexible measuring tape and weighed to the nearest $0.01 \mathrm{~g}$ with a Portable Electronic Balance.

Datum for all coordinates is WGS 84. All means are presented \pm one standard deviation (SD).

\section{Results}

We collected a gravid female Caraiba $a$. andreae $(420 \mathrm{~mm}$ SVL, $184 \mathrm{~mm}$ TL, $36 \mathrm{~g}$ ) on 27 May 2007 in the Protected Area "Sabanas de Santa Clara," Santa Clara, Villa Clara Province (22 $\left.24^{\prime} 09^{\prime} \mathrm{N},-79^{\circ} 55^{\prime} 01^{\prime \prime} \mathrm{W} ; 90 \mathrm{~m}\right)$. On the next day, we found a clutch of seven eggs inside the terrarium (Table 1: No. 1). Four hatchlings emerged on 26 July (59 days after oviposition) (Table 2: No. 1); the remaining eggs were non-viable (viability $57.1 \%$ ).
On 13 September 2007, we collected a gravid female C. a. orientalis ( $460 \mathrm{~mm}$ SVL, $210 \mathrm{~mm} \mathrm{TL}, 38 \mathrm{~g}$ ) near "Pico Cristal," Frank País, Holguín Province (20³2’35”N, $-75^{\circ} 28^{\prime} 26^{\prime \prime W}$; ca. 1,000 m). On 29 September (16 days after collection), we found a clutch of nine eggs inside the terrarium (Table 1: No. 2). Four hatchlings emerged on 3 December (65 days after oviposition) (Table 2: No. 2); the remaining eggs were non-viable (viability $44.4 \%$ ).

We placed an adult female $C$. a. andreae $(410 \mathrm{~mm} \mathrm{SVL}$, $210 \mathrm{~mm}$ TL, $37 \mathrm{~g}$ ) collected in February 2008 at the National Zoological Park, Boyeros, La Habana Province $\left(23^{\circ} 01^{\prime} 59^{\prime} \mathrm{N}\right.$, $-82^{\circ} 23^{\prime} 05^{\prime \prime W}$; $75 \mathrm{~m}$ ) with an adult male (400 mm SVL, 200 mm TL, $34 \mathrm{~g}$ ) collected in March 2008 near "Cueva Los Portales,” La Palma, Pinar del Río Province (2240’01”N, $\left.-83^{\circ} 28^{\prime} 35^{\prime \prime W} ; 130 \mathrm{~m}\right)$. We observed mating on 3 April 2008. Copulation lasted about $30 \mathrm{~min}$ after the first observation. Bodies were aligned and joined at the vent. During copula, the male continuously moved its head from side to side in a pendulum-like manner. On 15 April (12 days after copulation), we found a clutch of six eggs under the water bowl (Table 1: No. 3A). Between 1 and 9 May, two eggs became contaminated with fungi and were removed from the clutch. On 18-19 June (64-65 days after oviposition), four hatchlings emerged (Table 2: No. 3A) (viability 66.7\%). We left this pair together. Despite the fact that we did not observe a second copulation, on 28 June 2008 (74 days after first oviposition), we found another clutch of five eggs under the same water bowl (Table 1: No. 3B). Five hatchlings emerged on 21-22 August (54-55 days after oviposition; Table 2: No. 3B) (viability 100\%). 
Another pair of C. a. andreae (female: $450 \mathrm{~mm}$ SVL, 225 mm TL, 33 g; male: $420 \mathrm{~mm}$ SVL, $200 \mathrm{~mm} \mathrm{TL}, 29 \mathrm{~g}$ ) collected in February 2009, also at the National Zoological Park, was maintained together in captivity. Copulation was not observed, but on 17 April 2009, we found a clutch of six eggs in the terrarium (Table 1: No. 4). On 23-24 August (128129 days after oviposition), six hatchlings emerged (Table 2: No. 4) (viability 100\%).

On 3 March 2014, we found a clutch of five eggs of C. $a$. andreae under a rock about $25 \mathrm{~m}$ from the Almendares River,

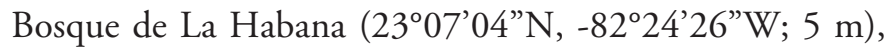
Playa, La Habana Province. When the hand of the observer approached to about $20 \mathrm{~cm}$ of the eggs, an adult emerged from under a nearby rock, moved close to the clutch, and adopted a threating posture (neck flattened dorsoventrally). This individual was collected but escaped before we could determine sex and take measurements. One egg accidentally broken during transportation contained a well-developed embryo. Another egg became detached from the clutch, cracked slightly at the point of junction and lost some fluid, but sealed naturally after a couple of days. On 27 May $(85$ days after collection), the shell of one egg was observed broken with the snake moving inside, sometimes extending its snout through the opening and retracting it again (Fig. 2A). This continued for two days, until the hatchling emerged on 29 May (Fig. 2B). The other three eggs hatched as well, but took only about one hour after the shell was initially opened (Fig. 2C-E) (Table 2: No. 5) (viability 100\%).

We also observed some hatchling $C$. a. andreae (identified by small size and the presence of umbilical scars) in nature. On 15 June 2009, two hatchlings (Table 2: No. 6) were found together under a rock in secondary grassland at Cañada Vieja $\left(22^{\circ} 20^{\prime} 11^{\prime} \mathrm{N},-79^{\circ} 40^{\prime} 55^{\prime} \mathrm{W} ; 200 \mathrm{~m}\right)$, Placetas,
Villa Clara Province. The two hatchlings shed on the same day. On 1 August 2013, a road-killed juvenile C. a. andreae (Table 2: No. 7) was found at the Cienfuegos Botanical Garden $\left(22^{\circ} 07^{\prime} 36^{\prime \prime N},-80^{\circ} 19^{\prime} 51^{\prime \prime} \mathrm{W} ; 70 \mathrm{~m}\right)$, Cienfuegos Province. On 11 November 2014, we found another roadkilled juvenile C. a. andreae (Table 2: No. 8, Fig. 3) at the botanical garden.

On 24 November 2014, we found a clutch of seven hatched eggs (Fig. 4A-B), referred to C. a. andreae on the basis of size and being adherent, under a rock near the ecological station at Las Terrazas in the "Sierra del Rosario" Biosphere Reserve (22 $50^{\prime} 59^{\prime}$ N, -82 $55^{\circ} 56^{\prime}$ W; $180 \mathrm{~m}$ ), Candelaria, Artemisa Province. On 3 May 2014, we found another clutch of seven hatched eggs (Fig. 4C), referred to C. a. nebulata, under an abandoned tractor wheel ca. $5 \mathrm{~km}$ $\mathrm{N}$ of the Colony Hotel at "Los Indios" Ecological Reserve $\left(21^{\circ} 40^{\prime} 41^{\prime \prime} \mathrm{N},-82^{\circ} 58^{\prime} 43^{\prime \prime} \mathrm{W} ; 5 \mathrm{~m}\right)$, Isla de La Juventud Special Municipality.

All of the eggs described herein were ellipsoidal in shape and off-white in coloration (Figs. $2 \& 4$ ), with fine longitudinal striations (Fig. 4B). Total clutch mass varied from 4.9 to $9.4 \mathrm{~g}$ (Table 1). On the day of hatching, a few hours before shells ruptured, eggs of most clutches collapsed. At hatching, the eggs were broken laterally, showing 1-3 longitudinal splits paralleling the striations (Figs. 2A-E). Hatching always occurred during the morning between 0900 and $1100 \mathrm{~h}$. Snakes inside eggs that were already broken ceased activity by midday and resumed efforts to emerge the next morning or even two days later (one egg from clutch No. 5).

The five hatchlings from clutch No. 3B increased in size over four months between 25 and $67 \mathrm{~mm}$ in total length $(\bar{x}$ $=41.7 \pm 22.3 \mathrm{~mm}$ ) and doubled their body masses for mean growth rates of $10.4 \mathrm{~mm}$ and $0.2 \mathrm{~g}$ per month. Hatchlings

Table 2. Measurements of hatchling Cuban Lesser Racers (Caraiba andreae). Measurements are listed as mean and range (in parenthesis). Totals listed as mean \pm one standard deviation.

\begin{tabular}{ccccc} 
No. & $\mathrm{N}$ & $\mathrm{SVL}(\mathbf{m m})$ & $\mathrm{TL}(\mathbf{m m})$ & Mass $(\mathrm{g})$ \\
\hline 1 & 4 & $119.8(110-131)$ & $58.0(51-63)$ & $0.9(0.7-1.1)$ \\
\hline 2 & 4 & $124.3(115-137)$ & $60.0(55-63)$ & $1.0(0.7-1.2)$ \\
\hline $3 \mathrm{~A}$ & 4 & $112.0(103-120)$ & $52.5(50-55)$ & $1.0(0.8-1.2)$ \\
\hline $3 \mathrm{~B}$ & 5 & $115.4(105-130)$ & $55.2(50-63)$ & $1.0(0.6-1.4)$ \\
\hline 4 & 6 & $126.8(112-140)$ & $56.3(50-61)$ & $1.1(1.0-1.1)$ \\
\hline 5 & 4 & $91.3(88-93)$ & $41.0(40-43)$ & $0.6(0.5-0.7)$ \\
\hline 6 & 2 & $121.0(120-122)$ & $54.0(52-56)$ & $1.2(1.1-1.2)$ \\
\hline 7 & 1 & 102.0 & 49.0 & 0.6 \\
\hline 8 & 1 & 109.5 & 49.0 & 0.6 \\
\hline Total & $\mathbf{3 1}$ & $\mathbf{1 1 5 . 5} \pm \mathbf{1 3 . 4}$ & $\mathbf{5 3 . 7} \pm \mathbf{6 . 8}$ & $\mathbf{0 . 9} \pm \mathbf{0 . 2}$ \\
\hline
\end{tabular}




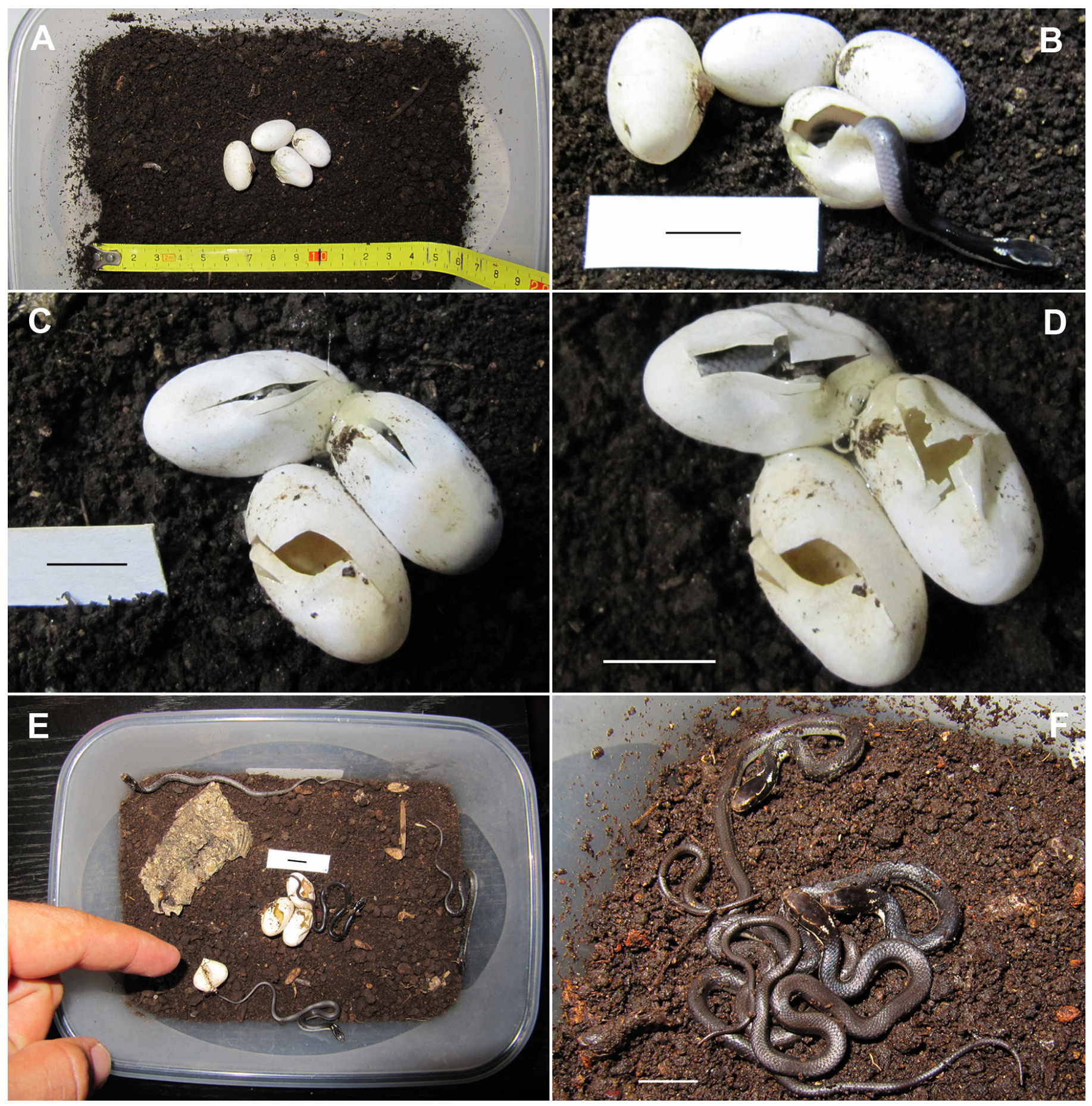

Fig. 2. Clutch of a Cuban Lesser Racer (Caraiba a. andreae) (No. 5 in Tables 1 \& 2) from near the Almendares River, La Habana Province: (A) Rupture of the first egg on 27 May 2014, (B-E) hatching on 29 May, (F) hatchlings shortly after emergence. Scale bars = 10 mm. Photographs by Alejandro Márquez.

$(\mathrm{N}=31$; Figs. 2E-F \& 3) usually are uniformly dark grayishbrown dorsally (occasionally uniformly light tawny brown), with darker heads and necks becoming progressively paler posteriorly. All had two more or less prominent whitish or cream canthal-temporal stripes, and some had pale yellowish ventrolateral pigmentation in the neck region. The nape, just behind the parietals, has two blurred to prominent sub- triangular to oval whitish spots. Ventral coloration can be grayish-white, pinkish-white, or greenish-white, the latter more evident on the posterior half of the body.

\section{Discussion}

Most reproductive activity of Caraiba andreae in nature apparently occurs during the rainy season, which is consistent with 

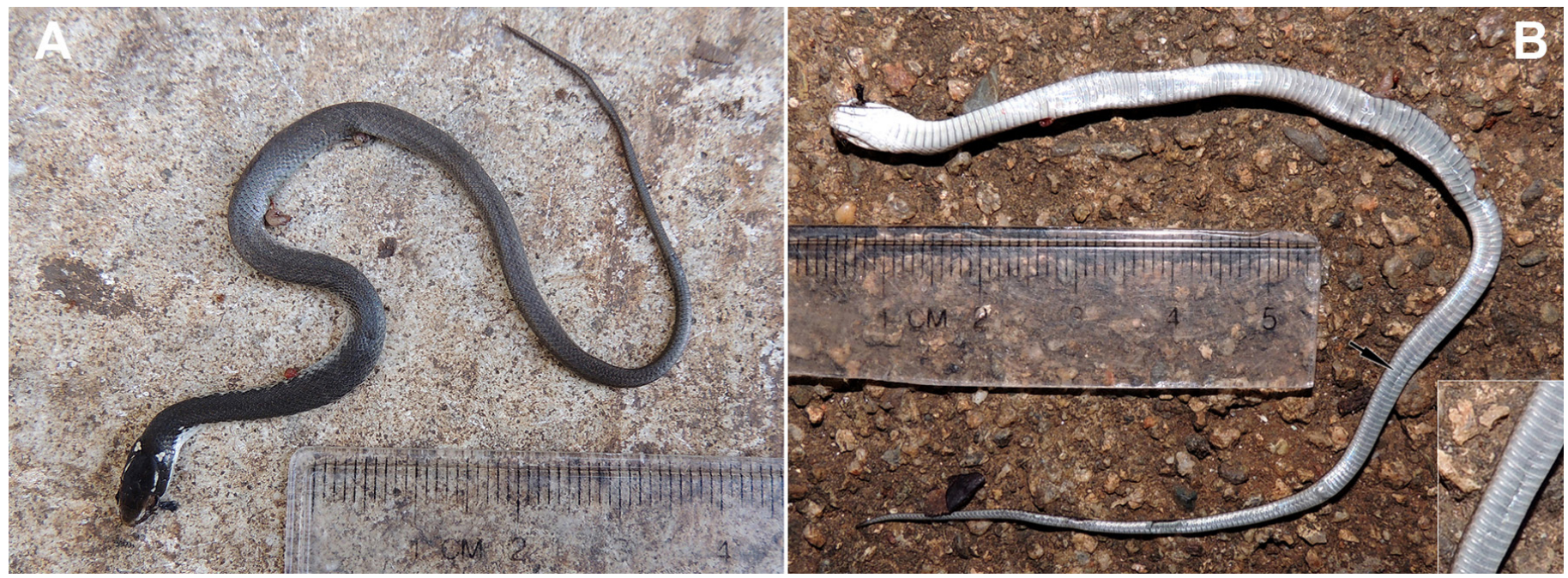

Fig. 3. Road-killed hatchling Cuban Lesser Racer (Caraiba a. andreae) (No 8 in Table 2) from the Cienfuegos Botanical Garden, Cienfuegos Province: (A) dorsal view; (B) ventral view, note the umbilical scar (arrow) detailed in the insert. Photographs by T.M. Rodríguez-Cabrera.

reports for other West Indian dipsadids (see Henderson and Powell 2009 for a review). Copulation and oviposition begin in April and hatchlings begin to appear in June (Schwartz and Henderson 1991; Estrada 1994; Fong 2004; this paper). However, the two consecutive clutches laid by female No. 3 (74 days apart), the gravid female collected at Pico Cristal in September, and the discovery of a free-ranging hatchling in early November, suggest that this species can reproduce at least twice in a single year.

Thomas and Garrido (1967) and Garrido and Schwartz (1969) commented on the possibility that the holotype and paratype of C. a. melopyrrha (an adult female and male, respectively), "collected together in a hole (...) in limestone" at Cayo Cantiles on 30 April 1966, were in copula when found because "one of them exuded some blood from its cloaca." Estrada (1994) mentioned two individuals of $C$. a. andreae found in copula in May at the "Lomas de Banao" Ecological Reserve, Sancti Spiritus Province. No detailed characterization of courtship behavior has been published.

The only case where we could register full gestation was in female No. 3 (12 days). However, female No. 2 oviposited 16 days after collection, during which it was isolated from conspecifics. Gestation in this case was similar to that of Cubophis cantherigerus (15-20 days; Schwartz and Henderson 1991; Fong and Garcés 2002; Arango 2008).

Adhered eggs also occur in other West Indian dipsadids, including Cubophis, Tretanorhinus, and Magliophis (see Henderson and Powell 2009 for a review). This could reflect a strategy to avoid egg rotation and embryonic death, as reptilian eggs lack a chalaza (e.g., Burt et al. 2007). Other reptilian groups (i.e., turtles, crocodiles, many lizards) bury their eggs in sediment, which at least in part reduces movement, but such a strategy is not common in snakes (Burt et al. 2007; Vitt and Caldwell 2009).
Mean incubation time of the eggs of $C$. andreae was $79.3 \pm 34$ days (54-129 days, $\mathrm{N}=23)$. This is similar to the range of 60-94 days reported for Cubophis cantherigerus (Novo and Arazoza 1986; Schwartz and Henderson 1991; Fong and Garcés 2002; Arango 2008). Shell texture of the eggs described herein coincides with descriptions in Schwartz and Henderson (1991) and Fong (2004). Clutch sizes in this species varied from 3-9 $(5.7 \pm 1.8 ; \mathrm{N}=10)$, but apparently ranges in nature to as many as 12 eggs (L.V. Moreno, pers. comm.).

Arango (2008) reported cessation and resumption of hatching activity in eggs of Cubophis cantherigerus. Rupturing of eggs was similar to that described by Fong (2004) for a clutch of four $C$. andreae eggs found in nature.

Grant (1957) described ontogenetic color change in a series of 37 individuals of $C$. a. orientalis from Banes, Holguín Province, noting that hatchlings from this population were light tawny brown dorsally and that gradually shifted to adult coloration as they grew. However, our observations indicate that hatchling coloration can be quite variable even within the same subspecies. We observed hatchlings with dorsal color patterns that coincided with Grant's descriptions of $C$. $a$. orientalis, but most were uniformly dark grayish-brown dorsally and grayish-white ventrally.

The defensive display observed in the adult $C$. andreae found near clutch No. 5 suggested not only that it was one of the parents, but also of some kind of "egg/nest guarding" not previously reported in West Indian oviparous snakes. Furthermore, the well-developed embryo found in the broken egg indicated that this clutch had been incubating for several days, possibly weeks, when found. The observation of an adult close to the clutch at that time and displaying aggressive behavior appears to supports a parental-care hypothesis. "Egg/nest guarding" or "egg attendance" in snakes is well 


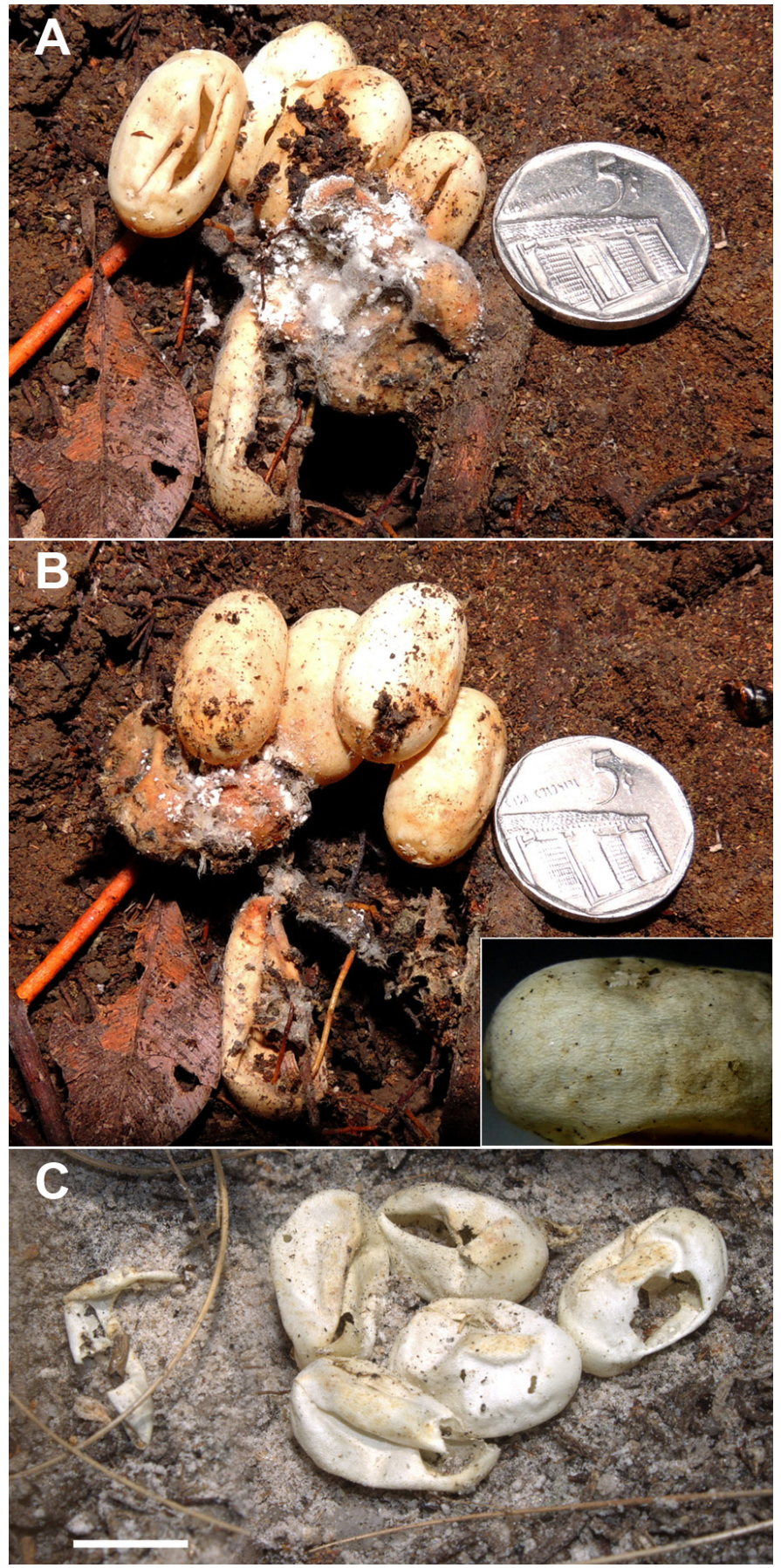

Fig. 4. Hatched egg clutches referred to Cuban Lesser Racers (Caraiba a. andreae): (A \& B) Las Terrazas, Artemisa Province: (A) as originally found, (B) turned over, shell texture detailed in the insert; (C) Los Indios Ecological Reserve, Isla de la Juventud. Coin diameter $=18 \mathrm{~mm}$, scale bar $=5 \mathrm{~mm}$. Photographs by T.M. Rodríguez-Cabrera (A, B) and R. Marrero (C).

documented in pythons and pitvipers (oviparous species), to a lesser extent in colubroids and Afro-Asian elapids, and rarely in leptotyphlopids (see Stahlschmidt and DeNardo 2011 for a review). Some species appear limited to passive care, but others (e.g., pythons and pitvipers) actively change physical parameters (temperature, humidity) that effect embryonic physiology and can aggressively defend eggs from intruders (e.g., some pit vipers; see Stahlschmidt and DeNardo 2011 for a review). Most clutches of $C$. andreae described in the literature (Fong 2004; Schwartz and Henderson 1991) and this work come from gravid females collected in nature and which later laid clutches in captivity - where parental attendance has not been observed. No. 5 was the first viable clutch found in nature. Consequently, inferences are tentative and more cases are required to corroborate such behavior in this species.

\section{Acknowledgments}

We thank Ansel Fong and the late Luis V. Moreno for providing literature and for a fruitful exchange of information. Raimundo López-Silvero helped with photographs. Alejandro Márquez collected clutch No. 5 and kindly provided all of the relevant information, including photographs and data on hatchlings.

\section{Literature Cited}

Arango Leyva, A. 2008. Reproducción en cautiverio de Alsophis cantherigerus schwartzi Lando y Williams, 1969 (Serpentes, Colubridae) en el Parque Zoológico Nacional de Cuba. Cubazoo 18:3-6.

Burt, D.B., P.F. Coulter, and D. Ligon. 2007. Evolution of parental care and cooperative breeding, pp. 295-325. In: B.G.M. Jamieson (ed.), Reproductive Biology and Phylogeny of Birds, Part B: Sexual Selection, Behavior, Conservation, Embryology and Genetics. Reproductive Biology and Phylogeny, Vol. 6. Science Publishers, Enfield, New Hampshire.

Domínguez Díaz, M. and L.V. Moreno García. 2003. Serpientes del suelo, pp. 98-109. In: L. Rodríguez Schettino (ed.), Anfibios y Reptiles de Cuba. UPC Print, Vaasa, Finland.

Domínguez Díaz, M., and L.V. Moreno García. 2006. Alsophis cantherigerus (Jubo, Jubo de Sabana, Jubo Sabanero). Size record. Herpetological Review 37:349.

Estrada, A.R. 1994. Herpetofauna de la Cuenca Banao-Higuanojo, Sancti Spíritus, Cuba. Revista de la Academia Colombiana de Ciencias 19:353-360.

Estrada, A.R. 2012. The Cuban Archipelago, pp. 113-125. In: R. Powell, and R.W. Henderson (eds.), Island lists of West Indian amphibians and reptiles. Bulletin of the Florida Museum of Natural History 51:85-166.

Fong G., A. 2004. Antillophis andreae (Black and White Racer, Jubito). Reproduction. Herpetological Review 35:57.

Fong G., A. and G. Garcés. 2002. Alsophis cantherigerus, mantenimiento y reproducción. Reptilia 34:55-57.

Garrido, O.H. 1973. Anfibios, reptiles y aves del Archipiélago de SabanaCamagüey, Cuba. Torreia, nueva serie 27:1-72.

Garrido, O.H. and A. Schwartz. 1969. Anfibios, reptiles y aves de Cayo Cantiles. Poeyana 67:1-44.

Grant, C. 1957. Dromicus in Cuba. Herpetologica 13:149-153.

Hedges, S.B., A. Couloux, and N. Vidal. 2009. Molecular phylogeny, classification, and biogeography of West Indian racer snakes of the Tribe Alsophiini (Squamata, Dipsadidae, Xenodontinae). Zootaxa 2067:1-28.

Henderson, R.W. and R. Powell. 2009. Natural History of West Indian Amphibians and Reptiles. University Press of Florida, Gainesville.

Novo Rodríguez, J. and F. de Arazoza Rodríguez. 1986. Cría en cautiverio de Alsophis cantherigerus (Ophidia: Colubridae). Reporte de Investigación del Instituto de Ecología y Sistemática 30:1-15.

Rodríguez Schettino, L., V. Rivalta González, and E. Pérez Rodríguez. 2010. Distribución regional y altitudinal de los reptiles de Cuba. Poeyana 498:11-20.

Schwartz, A. and R.W. Henderson. 1991. Amphibians and Reptiles of the West Indies: Descriptions, Distributions, and Natural History. University of Florida Press, Gainesville.

Stahlschmidt, Z.R. and D.F. DeNardo. 2011. Parental care in snakes, pp. 673-702. In: R.D. Aldridge and D.M. Sever (eds.), Reproductive Biology and Phylogeny of Snakes. Reproductive Biology and Phylogeny, Vol. 9. Science Publishers, Enfield, New Hampshire. 
Thomas, R. and O.H. Garrido. 1967. A new subspecies of Dromicus andreae (Serpentes, Colubridae). Annals of Carnegie Museum 39: 219-226.

Vitt, L.J. and J.P. Caldwell. 2009. Herpetology: An Introductory Biology of Amphibians and Reptiles. 3rd ed. Academic Press, San Diego, California.
Zaher, H., F.G. Grazziotin, J.E. Cadle, R.W. Murphy, J.C. Moura-Leite, and S.L. Bonatto. 2009. Molecular phylogeny of advanced snakes (Serpentes, Caenophidia) with an emphasis on South America xenodontines: A revised classification and descriptions of new taxa. Papéis Avulsos de Zoología 49:115-153. 